\title{
Review and Prospect of National Image Research -The Cuisine Elements for Further Study
}

\author{
Jianyao Li, Ping Zong* \\ Hilton School of Hospitality Management, Sichuan Tourism University, Chengdu, Sichuan 610100, China \\ *Corresponding author. Email: jianyaoli@foxmail.com
}

\begin{abstract}
National image is a broad research field attracts scholars from varies disciplines to study in different viewpoints and has tremendous research outcomes in past decades. This article aims to draw a picture in past research outcome in national image and particularly summarize research outcomes from scholars in China on national image research. Besides the above summarization, the article also raise an interesting research angle to consider impact of culture element to national image study, especially the food and cuisine originated from particular culture, for example, Szechuan cuisine is one of the eight local cuisines in China, how people's perception of Szechuan cuisine affects people's image building in China, research in this area will continue. Keywords: national image, review, culture, Chinese cuisine, Sichuan cuisine
\end{abstract}

\section{INTRODUCTION}

In recent years, Chinese government has put great efforts in the construction and dissemination of national image and aims to improve the country's soft power in culture. National image is a multi-dimensional complex. In the context of globalization, the national image represents the international community's comprehensive assessment of a country's political, historical, economic, and cultural dimensions, which is an important part of a country's soft power. Food is the most basic requirement of human beings, and culture is the blood of nations. Chinese cuisine and culture, which is based on the moral, social, and values of Chinese culture, is an important part of the nation's soft power building.

At present, the Chinese cuisine and culture in the international publicity is often through the holding of food festivals, to show the locality of the dishes and introduce the Chinese culture behind cooking in terms of time, the content, and the form of communication is relatively monotonous.

Chinese food as a medium for culture exchange has been mentioned many times but whether the prosperous international Chinese food festival has a long-term cumulative effect on the promotion of the national image cannot be answered. The cultural dimension has been considered as an indispensable representative dimension in a large number of domestic image research results in recent years [1-2] but no further researches were conducted.

\section{LITERATURE ON NATIONAL IMAGE}

\subsection{PREVIOUS RESEARCHES OVERSEAS}

National image is a concept derived from the study of origin effects in marketing. In the decades since Schooler proposed the origin effect in 1965 [3], many scholars have made in-depth research on the origin effect. Some initial studies have shown that consumers have an impression of a country based on their evaluation of the country's products. This country's image based on one or more products in turn affects consumers' evaluation of other products in the country and willingness to buy [4]. These scholars call this national impression obtained by judging the product as the national image, so Country-of-origin Image, Product-country Image and Country Image all represent the same concept for a period of time.

Research on consumer origin based on product origin in marketing research from single cue in the early 1960s to consumer purchase behavior in early1980s based on multifactors including origin image (multi-cue), and research on consumer purchasing behavior has developed quite well [5], and most of the relevant researches have shown that consumers' impressions or evaluations of the origin of a product have largely affected consumers' perception of the origin evaluation of the quality of domestic products, purchase intention or purchase behavior.

In the early 1990s, foreign scholars began to propose the concept of national image, and claimed that although the national image originated from country-of-origin, the concept of national image should be separated from the country-of-origin as a relatively independent research area. Scholars also pointed out that the national image is a broader and more representative concept of the image. It is not simple to represent the national image with stereotypes 
derived from products. For example, Martin and Eroglu defined the national image as an individual pair and a collection of information about the country in economic, social, cultural, political, and environmental aspects [6]. The "National Marketing" published by Philip Kotler in 1997 even promotes the country's image to a national brand strategy [7].

To evaluate the brand value of various countries, Simon Anholt proposed the "Six-Dimensional Model of National Brands", which considers national brands as the sum of people's understanding of the six dimensions of national competitiveness in the hexagon [8]. The six dimensions are: export, cultural traditions, tourism, government governance, investment and immigration, national residents.

Since 1990s, papers and monographs on China's national image have also been published with the enhancement of China's national strength. Foreign scholars mainly focus their research from the image of China in the eyes of westerners and the problems of China's national image. Joshua Kurlantzick's book "Glamour Offensive: How China's Soft Power Changes the World" revealed how China uses soft power to change the world and affects other developing countries, and he believed that China's soft power has posed a threat to the United States [9]. Joshua Cooper Ramo discussed the significance and the problems of China's national image, and the image of China in the eyes of Westerners in his book "Image of China: China in the Eyes of Foreign Scholars" [10]. And in the chapter "Light China", Remo concluded that China has a "distant, strange, complicated, and full of distrust" national image in the eyes of western countries. In the international political environment at that time, foreign scholars and political and business elites had a typical stereotype of the initial rise in China, and this impression was vividly shown in related papers, monographs and essays.

\subsection{PREVIOUS RESEARCH IN CHINA}

The study of national image started late in China, and it was not until the 1990s when the problem of shaping the image of the country was raised to the level of China's foreign strategy. Guan believes that "the national image is a complex, which is the external public of the country and the internal public to the country itself [11]. The overall evaluation and recognition given by the nation's actions, national activities, and results. The national image has great influence and cohesion, is a reflection of the country's overall strength, and is a strong intangible asset of the country."

Compared with western scholars' research largely based on the theory of the country of origin in the study of the national image, where mainly focus on the construction and influence of the national image from marketing, psychology and other aspects, Chinese scholars have a wider coverage of theoretical research on the national image. In summary, domestic scholars study the image of the country from the following aspects:

The first aspects is to consider the political dimensions of the national image from a political perspective. Wang, Chai,
Liu and other scholars have proposed to spread Chinese voices by constructing a foreign discourse system with Chinese characteristics, and to use Chinese thinking and international discourse to express Chinese sayings, making the national image prominent and the system clear [12-14]. The second is based on the brand communication theory to study how to shape the brand and image. For example, Wang and Chen proposed to strongly support a few qualified Chinese leading enterprises to create well-known international brands and promote the image of Chinese brands and Made in China [15]. Li, et al. tested the impact of the national image of the United Kingdom, the United States, and Australia on the quality of higher education in the country with Chinese students. Their conclusions based on more than 1,000 valid questionnaires indicated that the national image directly affected the interviews. Comment on the quality of higher education in the country [16].

The third is to conduct research from diplomatic and other related theories, and suggest that the country builds a national image of a responsible big country that cooperates for win-win and harmonious development. For example, Zhang and Wang believe that China's national image positioning should include a peaceful, developing, and harmonious national image [17], but Feng believes that shaping a true and objective national image can help change the stereotype of China [18].

The fourth aspect is from the perspective of communication, the shaping factors of China's national image are studied. Jiang and other scholars suggested that in addition to the official leading public opinion in the construction of the national image, the folk on the national image differentiation, the positive interaction of characteristics will bridge the blind spot of the national image dissemination [19]. Han believes that the shaping of national image is influenced by the cross-cultural environment, and in today's international community, where cultural soft power is highly competitive, the construction of China's national image should consider the conflict and collision between Chinese culture and foreign culture in the cross-cultural context [20].

The fifth is to explore the construction and influence of the national image from a specific field. Many scholars in the field of tourism believe that international tourism is an important channel for establishing the image of the country. Scholars put forward the concept of China's national tourism brand image by comprehensively studying the image of the country and the image of the destination. They consider it necessary to build a national tourism image that fully reflects the core values of the national tourism brand, and thus form a national tourism brand strategy that is internationally competitive [21-22]. Zhang, et al. took China as a case study and empirically tested the two-way relationship between the national image and the destination image and found that the national image is significantly positive impact on the destination image, and thus indirectly affect the loyalty of tourists [23]. The image of the destination also has a significant positive impact on the national image. Based on the BABDI model of destination image, Chen initially created a "China's national tourism image perception system based on destination branding" 


\section{FUTURE RESEARCH PLANNED}

tourism image perception system [24].

In addition to the extensive research conducted by the academic community on the construction and dissemination of the national image from different perspectives, the social survey institutions have also conducted several surveys on China's national image in the past few years. CIPG, Kantar Millward Brown, Lightspeed, a joint advisory body for the Foreign Affairs Bureau of China, for example, conducted five global surveys on China's national image. The fifth survey, released in January 2018, showed that China's cultural and technological image scored a bright spot in the country's image, with Chinese food becoming the most representative element of Chinese culture in the eyes of overseas respondents at a high rate of $52 \%$ [25].

\section{INADEQUANCY IN NATIONAL IMAGE RESEARCH IN CHINA}

Although studies on national image have produced fruitful outcomes in recent years by Chinese scholars, concerns and cautions are rising with several opinions:

\subsection{LIMITED RESEARCH METHODS}

Although the total number of research outcomes have greatly increased, but scholars also pointed out that research field and methods in this field is rather limited. Liu and Yang analysed research paper in past 5 years on the national image and results showed that quantitative research only count $16 \%$ in total published papers and a large number of research is based on speculative research (48\%) and qualitative research (36\%) [26].

\subsection{NARROWED CONCENTRATION}

Although the above-mentioned literature review involves different disciplines, showing that Chinese scholars involve more subject areas in the national image research, communication science and political science are still the main disciplines involved in national image research, and there are more analytical and countermeasure studies in the research results. More discussions are at the macro level, and less attention is paid to the in-depth study of specific individuals or dimensions.

\subsection{INADEQUATE COUNTERMEASURES FOR SHAPING AND DISSEMINATION}

Some scholars believe that the construction and dissemination of national image need to consider different regional and cultural receptors, and to use different strategies for different areas of warfare to build and disseminate the China's national image, but not to overamplify the role of mass media in communication [27].
Until now, the research on national image has focused on the overall and global perspective. Although such research can point the way for the construction of national image, it is impossible to grasp the essence of building unique national image covers all dimensions scientifically. The overall situation should be the starting point, and the subdivision and anatomical study of the whole situation can grasp the essence. Culture is one of the core competitiveness of a country. The charm of Chinese food is not only derived from its superb cooking skills, but also the cultural content it contains. Internationalizing Chinese cuisine is an important strategic component in building a national image at this stage. Based on this concept and realistic background, future research will be carried out empirically for in-depth study of the elements of Chinese food culture in the cultural dimension that make up the national image, take the internationalization of Sichuan cuisine as the research object, and mainly answer two questions:

First question to answer from a planned study is in the process of the internationalization of Chinese food, in what way to show the Chinese cuisine culture, which channels can better spread the Chinese food culture? The spread of culture can be represented by a symbol, can also be audiovisual communication as a medium, or the ceremony communication as a carrier, therefore, this study will particularly identify from what perspective to promote Chinese food culture is more effective and how to make it understood, transformed and accepted by audiences with different cultural backgrounds.

Which method can best integrate Chinese food culture in the construction of China's national image soft power is another concern. Although data from the Social Survey Agency show that nearly $80 \%$ of overseas respondents have been in contact with Chinese food, and $72 \%$ of those who have tried Chinese food have given a positive rating, but this does not mean that the respondents have an understanding of Chinese food culture, and many respondents may answer questions about their preferences for Chinese food. And there is no practical test of the effect of establishing and disseminating the national image through Chinese food culture. The research results available at present cannot give theoretical and practical guidance to this aspect. This is also the specific concern of a planned study on the second question.

\section{ACKNOWLEDGMENT}

This work was funded by Sichuan Cuisine Development Research Centre, a Humanities and Social Sciences Research Base of Sichuan Provincial Department of Education (CC19W01).

\section{REFERENCES}

[1] C. L. Duan, X. Lv, An empirical study on the national 
$175-183$

[16] J.Y. Li, F. Liu, José I. Rojas-Méndez, How international students select offshore programs: the influence of image, attitude, subject norm, and perceived behavioral control. Asia Pacific Education Review, 144 (3) $(2013): 381-390$.

[17] L.H. Zhang, L. Wang, Rising national image and international communication strategy. Chang Bai Journal, common market. Journal of Marketing Research, 2 (4) (1965) 394-397.

[4] A. Nagashima, A comparison of Japanese and US attitudes toward foreign products. Journal of Marketing, 34 (1) (1970) 68-74.

[5] C.M. Han, Country image: Halo or summary construct? Journal of Marketing Research. 26 (1989) 222-229.

[6] L.M. Martin, S. Eroglu, Measuring a multidimensional construct: Country image. Journal of Business Research, 28 (1993) 191-210.

[7] P. Kolter, S. Jatusripitak, S. Maesincee, The marketing of nations: A strategic approach to building national wealth, New York: The Free Press, 1997.

[8] S. Anholt, Competitive identity: The new brand management for nations, Cities and Regions, New York: Palgrave, 2006.

[9] J. Kurlantzick, Charm offensive: How China's soft power is transforming the world, New Haven: Yale University, 2007.

[10] J. C. Ramo, China's image: The country in the eyes of foreign scholars, Beijing: Social Sciences Academic Press (CHINA), 2008.

[11] W.H. Guan, China's image, Chengdu: UESTC Press, 1999.

[12] Y.G. Wang, Perspective on the main western ideology affecting the construction of mainstream ideology in China, Social Science Research, 1(2007) 6064.

[13] S.J. Chai, Reflections on the construction of Chinese discourse Power. The Contemporary World, 4 (2012) 34-36.

[14] T.L. Liu, Xi Jinping's strategic thinking of constructing foreign discourse system with Chinese characteristic. Journal of Hohai University (Philosophy and Social Sciences), 17 (1) (2015) 14-19.

[15] H.Z. Wang, Z.X. Chen, Research on the New International Positioning of Chinese Brand, Journal of Sun Yat-sen University(Social Sciences), 3 (3) (2010)
5 (2010) 39-42.

[18] X.N. Feng, Thinking on the spread of national image.

New West, 5 (2011)111-112.

[19] Z. Jiang, L. Li, Communication perspective: Complementary construction of official folk opinion field of national image. Journal of Central China Normal University (Humanities and Social Sciences Edition), 6 (2014) 84-91.

[20] L. Han, Cross-cultural communication analysis of national image. Theory Study Journal, 4 (2018) 49-50.

[21] L. Kuang, Research on China's National Tourism Image. Beijing: China Tourism Press, 2013

[22] M.C. Chen, China tourism destination branding image from perspective of affinity for travel and tourism: Smiling China. Tourism Forum, 11 (1) (2018) 38-47.

[23] J.R. Zhang, Y.Z. Chen, T. Chi, B.H. Wu, A.M. Morrison, An integrative model of destination image in a country context: A case study based on international tourists in Beijing. Tourism Tribune, 30 (03) (2015) 1322.

[24] M.C. Chen, China's tourism destination from the perspective of tourism branding: A perception system. Journal of Sichuan Tourism University, 1(2017) 67-71.

[25] CIPG, Kantar Millward Brown, Lightspeed. China National Image Global Survey 2016-2017, Beijing: China International Publishing Group, 2018

[25] Y.K. Liu, Z.X. Yang, Research on the national image in the new era: Status, deficiency and prospect, China Publishing Journal, 22 (2017) 3-8.

[27] X. Luo, Review of China's national image research, Journal of Guangxi Social Science, 9 (2017) 232-234. 